\title{
CIDADANIA E CONTESTAÇÃO SOCIAL: A LIBERDADE DE CRÍTICA E A FORMAÇÃO DO ESTADO REPRESSOR
}

Rodrigo do Prado Bittencourt*

\begin{abstract}
RESUMO
Este artigo se propõe a analisar a associação da Violência Estatal ao Sagrado e a desconstrução dessa ideologia na obra El ingenioso hidalgo Don Quijote de La Mancha, de Miguel de Cervantes. Tal desconstrução opera a partir do riso e revela o poder subversivo e contestador do "estranhamento" frente à vida social que ele causa. A Justiça deve estar a serviço do povo. A cidadania se faz em meio à liberdade. Contra os Estados Autoritários, o riso é arma subversiva de afirmação da democracia.
\end{abstract}

PALAVRAS-CHAVE: Cidadania; Estado; Violência; Liberdade; Princípios do Direito.

\begin{abstract}
Faced the increase of the Literature and Violence Studies, this paper aims to analyze the association between the State's Violence and the Sacred by the deconstruction of this ideology in the Miguel de Cervantes' book Don Quixote de La Mancha. This phenomenom operates from the laughter and reveals the subversive and contester power of the "strangeness" confronted of social life caused by it. Justice must be at the service of the people. Citizenship is done in the midst of freedom. Against the Authoritarian States, laughter is a subversive weapon of affirmation of democracy.
\end{abstract}

KEYWORDS: Citizenship; State; Violence; Freedom; Principles of Law.

\section{LETRAS, ARMAS e RELIGIÃO}

El ingenioso hidalgo Don Quijote de La Mancha não é comumente tratado como um livro violento. Não está ele, porém, repleto de atos de violência contra um inimigo que se afigura, do ponto

\footnotetext{
* Graduação em Ciências Sociais (USP, 2007), Mestrado em Teoria e História Literária (UNICAMP, 2013) e doutoramento em Literatura de Língua Portuguesa: Investigação e Ensino (Universidade de Coimbra, 2017).
} 
de vista da protagonista, como malvado? O Engenhoso Fidalgo não acredita na violência como instrumento para transformar a realidade social? Isso não abre um precedente lógico perigosíssimo, no que se refere ao campo dos direitos e garantias individuais assegurados pelo art. $60, \S 4^{\circ}$, IV? No limite, o que a Ditadura Civil-Militar que oprimiu o povo brasileiro de 1964 a 1985 não fez, guardadas as devidas proporções, exatamente a mesma coisa: não tentou também ela realizar aquilo que dizia ser bom, a partir da força?

Na Mancha do século XVI, um decadente fidalgo saudoso do tempo da cavalaria andante resolve ressuscitar tal instituição, "socorriendo viudas, amparando doncellas y favoreciendo casadas, huérfanos y pupilos, propio y natural oficio de caballeros andantes" (p. 128 da Parte II), e vê a violência como meio de transformação social. Para mudar o mundo, ele não recorre às Letras, mas às Armas. Essa oposição aparece muitas vezes de modo claro no livro de Cervantes (ver, sobretudo, o capítulo XXXVIII da Parte I: "Que trata del curioso discurso que hizo don Quijote de las armas y las letras". Páginas 478 e seguintes), o que mostra uma clara opção pela violência e não pelo diálogo, por parte de Dom Quixote.

Há aqui uma comparação entre a vida militar e a vida de estudos. Dom Quixote não ousa dizer que a vida das Armas é superior à Eclesial, mas diz que as Armas superam às Letras e busca, por meio das primeiras, servir a Deus, ou pelo menos é assim que ele gosta de se ver, como demonstra o já citado capítulo XXXVIII da Parte I. Assim, mediante uma realidade que pressupõe a ausência de um poder centralizado no Estado e, portanto, na ausência de um árbitro imparcial para dirimir conflitos, Dom Quixote pensa em cumprir a função de ajudar os mais fracos frente à tirania dos fortes, sendo este árbitro. Tal contexto, porém, é típico das novelas de cavalaria e não mais de sua época, o que faz do paladino um deslocado no tempo e na dinâmica social, alguém que não percebe as "regras do jogo", o que suscita a comicidade presente na obra.

Dom Quixote busca a glória pessoal e a fama por meio do auxílio prestado aos outros, ou, ao menos, do que ele acredita ser isso. Tudo o que ele faz, portanto, se reveste de uma expectativa de ser reconhecido e admirado como grande cavaleiro andante, fazendo com que reine uma impostação heroica em todas as suas ações. Dom Quixote é alguém que representa um papel, mas o faz 
acreditando na sua própria representação. Sendo espetáculo e espectador ao mesmo tempo.

A comicidade de suas aventuras e a relação entre o sonho e a realidade muitas vezes, porém, desviam a atenção do leitor de seu lado violento. É preciso analisar se tais coisas são suficientes para tornarem a violência inócua, ou irrelevante. Ao contrário, não seria ainda mais assustador quando até um sonhador como Dom Quixote, capaz, ao que parece, de acreditar em qualquer ilusão que animasse seu espírito, baseia seus devaneios justamente na violência? Isso nos remete ao comentário do jurista Fabio Konder Comparato a respeito do filósofo francês Étienne La Boétie. Comparato destaca os fatores que La Boétie aponta como responsáveis por explicar a servidão voluntária e dentre eles está a degradação moral da vida coletiva. Degradação que chega ao ápice quando até os sonhadores mais doces passam a acreditar na violência e imitar os brutos:

É de completa evidência, prossegue o autor, que somos todos igualmente livres, pela nossa própria natureza; e que o liame que sujeita uns à dominação dos outros é algo de puramente artificial. Mas então, como explicar que esse artifício seja considerado normal e a igualdade entre os homens não exista praticamente em lugar nenhum?

Para explicar esse absurdo da servidão voluntária, La Boëtie aponta algumas causas: o costume tradicional, a degradação programada da vida coletiva, a mistificação do poder, o interesse. (COMPARATO, 2011)

\section{A DEFINIÇÃO TROTSKISTA DE ESTADO}

Para se entender a relação entre violência e riso em Dom Quixote é preciso recorrer a algumas transformações sociais iniciadas na época de Cervantes e que repercutem na atualidade. Sobretudo a formação do Estado Nacional e aquilo que o líder bolchevique Leon Trótsky chamou de "monopólio legítimo do uso da força"; definição que acabou sendo adotada pelo sociólogo alemão Max Weber (WEBER, 1982, p. 98). Com efeito, Dom Quixote, em sua loucura, age como se estivesse na Idade Média e não na Idade Moderna, num dos países com o Estado mais bem organizado e poderoso da Europa, naquele momento: a Espanha. 
Essa formação histórica, o Estado Nacional, com seu poder centralizado e em busca de cada vez maior exclusividade no uso de meios violentos, se liga à representação que se faz da violência. A partir do Estado Nacional, o uso da violência por um cidadão comum vai ser cada vez mais reprimido. Ele já não pode usá-la para defender-se, o que contribui também para o controle cada vez maior de sua animalidade e de seus instintos, na construção daquilo que é chamado de Civilização (Elias, 1995).

No ordenamento jurídico brasileiro, percebe-se a existência de monopólio, ainda que ele não apareça explicitado na forma de uma norma específica ou mesmo de um princípio. Existem, todavia, inúmeras normas que acabam por estruturar o monopólio estatal da violência, no Brasil. Assim, toda sanção penal é aplicada pelo Estado. A exceção encontra-se tão somente no Estatuto do Índio: Lei No 6.001, de 19 de dezembro de 1973, art. 57: "Será tolerada a aplicação, pelos grupos tribais, de acordo com as instituições próprias, de sanções penais ou disciplinares contra os seus membros, desde que não revistam caráter cruel ou infamante, proibida em qualquer caso a pena de morte".

Outro aspecto que nos permite perceber a construção deste monopólio são as normas que punem a formação de grupos armados, como o art. 288-A do Código Penal (Decreto-Lei n ${ }^{\circ} 2.848$, de 7 de dezembro de 1940):

Constituição de milícia privada (Incluído dada pela Lei $\mathrm{n}^{\circ} 12.720$, de 2012)

Art. 288-A. Constituir, organizar, integrar, manter ou custear organização paramilitar, milícia particular, grupo ou esquadrão com a finalidade de praticar qualquer dos crimes previstos neste Código: (Incluído dada pela Lei $\mathrm{n}^{\circ} 12.720$, de 2012)

Pena - reclusão, de 4 (quatro) a 8 (oito) anos.

Este artigo foi incluído recentemente, como se vê, graças ao grave problema com milícias armadas no Estado do Rio de Janeiro, mas a Constituição já previa limites e proibições ao uso de armas por grupos organizados militarmente ou não. Assim, o art. $5^{\circ}$, XVI da Constituição da República Federativa do Brasil de 1988 diz que "todos podem reunir-se pacificamente, sem armas, em locais abertos ao público, independentemente de autorização, desde que não 
frustrem outra reunião anteriormente convocada para o mesmo local, sendo apenas exigido prévio aviso à autoridade competente". Percebe-se que esta proibição do uso de armas alcança não apenas grupos militarmente treinados e hierarquizados, mas qualquer união aleatória de indivíduos armados. Assim, o direito de protestos e manifestações constituem direitos constitucionais, mas desde que os membros destas reuniões estejam desarmados.

Tendo vedada reunião de quaisquer grupos de pessoas armadas, a Constituição da República Federativa do Brasil de 1988 já estava abarcando qualquer organização guerrilheira, paramilitar e/ou meramente criminosa, mas os constituintes quiseram ser ainda mais explícitos e no inciso seguinte condenaram a ação paramilitar: "é plena a liberdade de associação para fins lícitos, vedada a de caráter paramilitar" (CF 1988, art. 5, XVII).

Não obstante estes dois incisos, o mesmo artigo traz ainda outro, reforçando novamente, de modo até mesmo relativamente prolixo, a proibição do uso de armas por grupos de cidadãos: XLIV - constitui crime inafiançável e imprescritível a ação de grupos armados, civis ou militares, contra a ordem constitucional e o Estado Democrático $(\mathrm{CF}$ 1988, art. $\left.5^{\circ}, \mathrm{XLIV}\right)$. Interessante notar que o artigo $5^{\circ}$ reúne os principais direitos e garantias individuais do cidadão e mesmo dos estrangeiros. Assim, este inciso destoa dos demais por seu caráter penalista de norma negativa, limitadora da ação do indivíduo. Os outros dois transcritos anteriormente trazem algum direito, ainda que especificamente restrito por uma consideração limitatória da ação normatizada. O inciso XLIV, entretanto, não traz nenhum direito, mas apenas uma proibição; uma proibição que é acompanhada de duas regra acerca de elementos do Direito Penal: a fiança e a prescrição.

Não obstante a vedação à punição fora da alçada do Estado e à criminalização de grupos armados, há ainda que se considerar como elemento constituinte do monopólio legítimo da violência as proibições e os rigorosos limites impostos aos particulares que desejem ter uma arma. O Estatuto do Desarmamento (Lei 10.826/03) é extremamente claro e detalhado, no que se refere ao fato de que apenas alguns grupos, muito bem especificados, poderão ter porte de arma de fogo (vide o art. $6^{\circ}$ desta lei).

Assim, o momento em que Cervantes escreveu sua obra-prima é de extrema importância para esta questão, pois tratava-se de um 
contexto em que o monopólio estatal da violência já estava assegurado nos Estados Nacionais da Europa Ocidental. Dom Quixote é alguém que não se percebe dentro desse contexto social e age de forma a arrogar para si o poder de usar da violência, agora centralizada no Estado. O que faz dele um concorrente e, portanto, um inimigo deste ente político. Seu referencial de conduta é outro, pertence não ao seu tempo, mas ao passado. O diferente, o "outsider", sofrerá a repressão por sê-lo (DURKHEIM, 2011), o que explica as várias vezes em que o fidalgo e Sancho são moídos de pancadas.

\section{A JUSTIÇA A ENCARGO DE PARTICULARES, NA AUSENCIA DE UM PODER CENTRAL: A EUROPA MEDIEVAL}

Num contexto em que os homens nobres eram treinados para a guerra desde meninos, mas nem todos tinham uma colocação social estável e segura (uma vez que o Direito de Primogenitura deixava os irmãos mais jovens em uma situação não muito confortável) alguns destes nobres sem boa colocação social forneceram bons braços para guerras. Estas eram oportunidades para que eles alcançassem um feudo, um casamento vantajoso ou mesmo aumentar sua riqueza, quando nelas conquistavam espólios valiosos.

A partir desse estrato social será fundado um imaginário que corresponde ao modelo idolatrado por Dom Quixote: o do cavaleiro andante. $\mathrm{O}$ fato de ele deixar Rocinante seguir o caminho que quisesse (p. 34 da Parte I), ao sair em sua primeira viagem em busca de aventuras, mostra a consciência que tinha de que esses cavaleiros estavam nas mãos da sorte e da fortuna, sem terem uma rotina estruturada e uma atividade organizada.

Dentro de uma sociedade profundamente religiosa, porém, isso não poderia deixar de ser simbolizado religiosamente e assim integrado ao resto do imaginário social. É preciso, porém, pensar que as formas dessa(s) religiosidade(s) $\operatorname{era}(\mathrm{m})^{1}$ diferentes das formas

\footnotetext{
${ }^{1}$ Cabe muito bem o plural (religiosidades), porque, independentemente da definição que se queira dar a este termo, é fácil de perceber que o modo como os eruditos monges viviam sua religiosidade era distinta da do povo, ignorante e sofredor. Isso sem falar em heresias, sincretismos, correntes teológicas distintas, variações nacionais e de classe.
} 
atuais. Assim, os cavaleiros não cumpriam uma função apenas dentro do sistema guerreiro, mas a justificativa ideológica de sua ação e do domínio de sua classe se amparava na religião. Para conhecer então a lógica que regia as atividades cavalheirescas é preciso inseri-la em seu contexto geral e não se pode fazer isso sem tocar no assunto $\mathrm{da}(\mathrm{s})$ religiosidade(s).

A crença do século XIII está gravada numa obra que se tornou um dos livros mais lidos do final da Idade Média e começo da Moderna, sendo valorizado como dotado de modelos de vida a serem seguidos por todos: a Legenda Aurea, ou Legenda Sanctorum. Este livro foi tão importante para a economia simbólica deste momento que chegou a ter mais edições que a própria Bíblia e influenciou inúmeros outros escritos da época, podendo ser considerado talvez a mais influente obra dos séculos XIV e XV, na Europa. Isso, certamente não autoriza ninguém a pensar que toda a religiosidade da época era una, indivisa e exatamente igual à retratada na Legenda Aurea, mas esta obra se mostra importante por sua popularidade e por ser testemunha de uma época de poucos registros escritos. Além do que, o fato de sua pertinência ou não com a realidade pouco importa aqui, uma vez que se quer descobrir justamente a posição ideológica tomada para justificar a dominação dos nobres e como ela foi formulada no que tange aos guerreiros admirados por Dom Quixote.

Se analisarmos as narrativas da Legenda Aurea, e os diversos milagres que elas contêm, veremos que muitos deles referem-se não a curas maravilhosas, ou revelações súbitas, por meios místicos, da vontade divina, ou a atribuição de uma missão especial para um escolhido... enfim, não se tratam apenas de milagres que se referem ao sobrenatural e que só poderiam mesmo ser realizados por Deus. Algumas dessas narrativas, e são essas as que mais interessam para entender Dom Quixote, versam sobre milagres realizados por Deus para modificar as relações humanas; para fazer justiça, como qualquer juiz deveria fazer.

Como a justiça estava nas mãos dos senhores feudais, ela não podia ser imparcial. Além do que, estes senhores tinham domínio apenas sobre a região de seu feudo, ficando o peregrino e viajante em situação difícil: como este poderia ir a outro feudo e acusar um dos moradores desse local de um crime? Iria ter de fazê-lo perante um senhor que conhecia esse morador e que muitas vezes preferiria ser 
conivente com um criminoso que fosse seu patrício e vassalo a auxiliar um estrangeiro que em nada pudesse lhe beneficiar.

Além do mais, mesmo quando os crimes aconteciam dentro dos limites do feudo e envolviam apenas moradores locais, os senhores feudais nem sempre tinham boa vontade em julgá-los, uma vez que estavam mais preocupados consigo que em trabalhar para uma justiça que gastará seu tempo sem lhe trazer mais terras ou mais dinheiro. Julgar um caso era fazer um favor e nem sempre era visto como uma obrigação, o que fazia que a justiça só fosse levada a sério quando o interesse dos poderosos estava envolvido. Por fim, na falta de um corpo policial burocrático eficiente (inspetores, peritos, detetives...), mesmo um senhor feudal que atuasse como um juiz justo e dedicado pouco poderia fazer.

Diante disso, a fé afirmava que só Deus poderia ser um justo juiz e muitos preferiam pedir proteção a Ele que procurar o senhor feudal. Para ilustrar tais milagres realizadores da justiça entre os homens, vejamos uma pequena narrativa, referente a um milagre feito por São Tiago, o Maior:

Um mercador, injustamente espoliado e aprisionado por um tirano, era devoto de São Tiago e invocou seu auxílio. São Tiago apareceulhe e, diante dos guardas, levou-o ao alto da torre, que se curvou até ficar no nível do solo, permitindo ao mercador descer dela e ficar livre sem sequer precisar saltar. Os vigias tentaram persegui-lo, mas não podiam vê-lo. (VARAZZE, 2003, p. 568)

Vê-se claramente como algo que hoje é visto como do âmbito da ação humana, julgar um conflito de interesses e promover a justiça, era visto como do âmbito das ações divinas, sendo Deus o único capaz de corrigir verdadeiramente as injustiças das relações humanas. Assim, quando esses cavaleiros seguiam o propósito de promover a justiça, eles estavam se aproximando da divindade e dos santos. Estavam agindo como imitadores de Cristo promovendo o Reino de Deus. Há que se lembrar que o santo da narrativa, São Tiago, segundo a lenda, apareceu armado como cavaleiro numa batalha entre cristãos e muçulmanos na Espanha, lutando ao lado dos primeiros. Crendo nisso, muitos fiéis peregrinavam do Sul da França à Compostela, no Noroeste da Espanha, onde fica localizada uma catedral dedicada a este santo. 
Não é à toa que as pessoas atribuíam tanta importância às lutas dos cavaleiros andantes; eles tinham mais independência e disposição para fazer justiça que os feudatários. Como nobres sem feudos, poderiam usar de armas e oferecer seus serviços na guerra, mas entre uma batalha e outra costumavam tomar partido em litígios de camponeses, sendo por eles procurados para isso. Assim, aos poucos, a tradição do Direito Romano vai se misturando ao Direito Germânico, consuetudinário, e às tradições cristãs. A cavalaria andante traz em si o elemento da forte independência e altivez individual, típicas da cultura germânica, com a fé cristã, herdada do mundo romano. E será por meio da fé cristã que virá aos povos não romanizados a tradição jurídica do império dos césares. Este amálgama ocorreu lentamente, ao longo de séculos, como afirma Noberto Bobbio:

O Direito Romano se eclipsou na Europa Ocidental durante a alta Idade Média, substituído pelos costumes locais e pelo novo direito próprio das populações germânicas (ou bárbaras). Mas depois do obumbramento ocorrido em tal período - obumbramento comum, de resto, àquele de toda a cultura, ressurgiu no primeiro milênio com o aparecimento da Escola Jurídica de Bolonha e difundiu-se não apenas nos territórios sobre os quais já se havia estendido o Império Romano, mas também sobre outros territórios jamais dominados por este: sobretudo na Alemanha, onde ocorreu no início da Idade Moderna o fenômeno da "recepção", graças ao qual o direito romano penetrou profundamente na sociedade alemã (basta pensar que ainda no fim do século XIX - antes grandes codificações ocorridas no início do século XX - aplicava-se nos tribunais germânicos o direito do Corpus juris - naturalmente modernizado e adaptado às diferentes exigências sociais - sob o nome de "usus modernus pandectarum "; o direito romano difundiu-se, por outro lado, também nos Países Baixos, nos escandinavos e, ainda que em medida mais limitada, na própria Inglaterra (BOBBIO, 1995, 30).

Os cavaleiros andantes gostavam de serem vistos como verdadeiros continuadores das ações de Cristo e dos Santos, promovendo a paz e a justiça evangélicas na terra. E parece que assim eram vistos por Dom Quixote. O discurso em que ele defende as Armas diante da escolha pelas Letras escolha é muito elucidativo: embora, neste discurso, ele valorize a vida religiosa como a mais 
perfeita, mostra ter orgulho de sua opção pelas Armas e revela ter disposição em continuar nesta senda. O imaginário cristão estava fortemente presente em torno da figura do "cavaleiro andante"; era, em tese, o motivo pelo qual o cavaleiro deveria sair pelo mundo "a fazer o bem".

A busca de fama e glória e recompensas como feudos ou casamentos com princesas, entretanto, "dessacralizam" as atividades do cavaleiro andante; uma vez que, mesmo mediante a força da religião cristã, elas se revelam como atividades não totalmente desinteressadas; embora precise afirmar seu desinteresse para que a atribuição de suas recompensas possa ser feita, segundo a lógica do campo ${ }^{2}$.

Essas personagens, admiradas pelo Fidalgo, representavam, para ele, o símbolo da abnegação, da valentia e da virtude e é por serem apreendidos dessa forma que o motivarão a querer ser visto assim por seus contemporâneos. De fato, a fama que torna conhecidos os feitos gloriosos alcançados nas lutas contra a injustiça seria bem-vinda, na Idade Média, por trazer a recompensa por tantos sacrifícios. Não é à toa que Dom Quixote promete a Sancho uma ilha. Ele tem consciência de que seus feitos podem trazer como remuneração cargos sócio-políticos e vantagens econômicas.

Ao contrário de Sancho, porém, que deseja ávida e notoriamente esta prebenda, Dom Quixote assimilou tão bem o discurso ideológico transmitido nos livros de cavalaria - de nobres abnegados, amantes dos feitos gloriosos e da vida de devotamento às Armas - que não mascara um desejo de recompensa materiais. Ele sequer alimenta tais sonhos.

Pode-se dizer, pois, que o Cavaleiro da Triste Figura é um homem a querer viver no seu tempo a realidade política do passado, já inexistente. Afinal, a figura que deseja encarnar é notadamente uma figura de justiceiro e, portanto, política; a saber: um modo de resolver os conflitos dentre os homens. Ele, ao assumir a ideologia que circunda tal figura, porém, acaba por levá-la a uma situação social que ela jamais teve, a não ser nos livros por ele lidos.

\footnotetext{
${ }^{2}$ Como a arte, segundo Bourdieu (1996). Esta também, para ser respeitada como tal, deve parecer abnegada e como tendo um fim em si mesmo. Esta "aparência" é essencial para as recompensa sociais, mas não o bastante. A "qualidade" deve estar presente nas obras. Assim, também a abnegação não é o suficiente para o cavaleiro errante: ele precisa ser vitorioso para conquistar feudos, um bom casamento ou qualquer outra recompensa.
} 
Com efeito, Dom Quixote é um cavaleiro que não almeja deixar de sê-lo; que não vive o caráter de transitoriedade típico desta posição. Afinal, a vida de "cavaleiro andante" não passava de um pré-requisito para uma situação confortável de estabilidade e segurança (representada nos interesses de Sancho como o governo de uma ilha). A violência presente na empreitada e os riscos que ela poderia trazer apenas justificavam-se diante dos altos prêmios que poderiam ser conquistados.

Dom Quixote quer apenas os riscos e não os prêmios, o que faz dele uma personagem ainda mais cômica do que já é. Prova de que é cômico não apenas para quem lê, mas também para as outras personagens, são as inúmeras vezes em que alguém dele ri e que as outras personagens buscam incentivar sua fértil imaginação apenas para divertirem-se às suas custas e de Sancho.

\section{RISO E SUBVERSÃO}

A busca de glória e fama não é vista como oposta ao Cristianismo, mas elas se ligam a ele, num sincretismo que permite a sobrevivência da religião, mesmo diante de valores que não lhe correspondem, como se verá mais adiante. É importante ter isso em mente para entender como Dom Quixote dignifica, também por associação à religiosidade, sua atividade guerreira.

O modelo da Legenda Aurea está tão fortemente ligado ao das histórias de cavalaria que mesmo algo que parece hoje avesso ao Cristianismo, como magos e feiticeiros - e que vai ter papel importantíssimo nas aventuras quixotescas, por meio da figura do encantador maléfico - nela aparece. Ainda com relação ao mesmo São Tiago, citado anteriormente, vê-se uma historieta em que ele vence um mago que usa do domínio sobre os poderes sobrenaturais malignos e de magia para prejudicar o santo.

Dentre as ações extraordinárias do mago, de nome Hermógenes, estão as de paralisar um homem que fora seu aprendiz, Fileto - agora convertido por Tiago - e a mobilização de "demônios para que trouxessem Tiago e Fileto amarrados, porque queria vingarse deles". Expedientes que falham, pois Tiago liberta Fileto dandolhe um lenço e pedindo que ele dissesse uma determinada jaculatória e envia de volta os demônios para Hermógenes, para o trazerem amarrado, coisa que acontece. 
Ora, vê-se que crença no poder da magia não fora sempre condenada pelo Cristianismo, mas que conviveu por um tempo de maneira sincrética com ele; sendo a boa magia atribuída aos santos, pela graça de Deus, e a má aos demônios e seus sectários. Daí vê-se o quanto a visão de mundo do Cavaleiro da Triste Figura se liga ao imaginário cristão e quanto de suas ações não fazem referência a ele. De modo que suas aventuras em prol dos fracos e injustiçados não podem ser entendidas fora desse contexto. Elas seriam uma nobre continuação, por meio das armas, da ação dos santos e quem as realiza se mostra, de certo modo, como um enviado da Justiça Divina: ao menos, esta parece ser a visão de Dom Quixote. É preciso entender isso para entender como o Fidalgo estava deslocado de sua realidade presente, imbuído de uma ideologia cristã e guerreira da Idade Média. Num contexto de Estado Nacional já formado, com um poder de polícia e uma justiça cada vez mais organizados e eficazes, não cabe a ação da justiça privada encampada por Dom Quixote.

O Cavaleiro da Triste Figura vive do passado, e de um passado idealizado; o que reforça seu caráter de sonhador, desajustado, "outsider", e também a comicidade do texto. Comumente, se ri de quem foge aos padrões, seja como punição, seja porque a imensa maioria das pessoas de uma sociedade introjeta de tal modo suas regras que não pode deixar de vê-las como de validade absoluta e incontestável e por isso óbvias. Alienam-se, assim, da lembrança de quanto estas regras sociais pareceram arbitrárias e estranhas ao primeiro contato. Muitas representações que são feitas das crianças como livres e espontâneas vêm do fato de elas simplesmente não conhecerem as regras pelos adultos já interiorizadas e respeitadas. A mesma liberdade frente ao padrão, porém, poderia ser encontrada nos adultos, se eles não o conhecessem.

Este é o caso, sobretudo, do estrangeiro, que, por não conhecer as regras do mundo social em que se insere, pode provocar a mesma comicidade. É o que se vê nos relatos de muitos antropólogos que, por não conhecerem as regras sociais de comportamento das tribos que estão a estudar, são inclusive classificados socialmente como crianças e obrigados a conviver apenas com elas. Ao menos até se educarem na nova cultura.

Dom Quixote insere toda sua busca por uma nova realidade a seu ver, mais justa - mediante a inserção imaginativa num contexto 
que não corresponde ao real. É a partir daí que ele vai praticar atos de violência que já não têm lugar no presente, uma vez que a violência, no novo cenário histórico, encontra-se sequiestrada pelo Estado e agora é sua prerrogativa e privilégio. Afinal, como já se disse, está-se já num momento histórico em que está presente a figura do Estado Nacional e a definição que se pode dar, a partir de Weber, deste ente político, é a de "monopólio legítimo do uso da força" (WEBER, 1982, p.98).

\section{DIREITO E VIOLÊNCIA, SEGUNDO WALTER BENJAMIN}

Confirmando esta visão, o filósofo alemão Walter Benjamin afirma que violência e poder são realidades indissociáveis em nossa História e que o Direito - que, segundo ele, busca, antes de tudo, se preservar e se reproduzir - não é nada mais que um aparato de poder constituído para coibir qualquer violência fora do âmbito do Estado e, sobretudo, contra ele. O filósofo usa a palavra alemã "Gewalt", que significa tanto "poder" quanto "violência", para referir-se à força exercida pelo Estado.

Assim, a violência não é estranha ao dia-dia, mas ao contrário, se faz presente o tempo todo. O Estado só detém seu poder político porque o baseia no uso da violência e não de qualquer violência, mas naquela organizada e impessoal. Exige-se, por exemplo, que um policial que use de violência só o faça se necessário e não por gozo pessoal. Se a violência legítima é aquela exercida quase que a contragosto do executante e apenas em caso de extrema necessidade, exige-se que seu executor seja sereno, racional, humano e que não se deixe seduzir pelos atrativos do poder conferido pela violência. Exige-se também que assuntos relacionados à violência sejam tratados com seriedade e serenidade, sem aproximá-la do riso e do chiste; isso é muito mal visto. Rir do sofrimento alheio impingido por algum ato violento é visto como extremamente condenável e desumano.

Aí está o poder que El ingenioso hidalgo Don Quijote de La Mancha tem de impressionar e fascinar: este livro aproxima elementos que parecem completamente opostos entre si - a violência e o riso. Ele o faz, afastando o uso de violência de toda a pompa e altivez a que ela se uniu no imaginário ocidental moderno, 
mostrando o executor do ato violento não um grande e poderoso, mas um parvo (o próprio Dom Quixote).

Historicamente, no Ocidente, a violência se uniu ao Estado. Então é interessante perceber que ela se revestiu da mesma pompa e eloqüência que o Estado e o soberano reservaram para si. Dom Quixote, por sua vez, destrói essa pompa com o riso que ele provoca ao exercer uma violência evidentemente pomposa e elegante - ele faz questão de manter a aparência de nobre e grandioso, ainda que com meias rasgadas, corpo moído de pancadas e barriga vazia contra objetivos inexistentes (gigantes que são moinhos de ventos, por exemplo) ou de modo ineficaz (querendo defender mas na verdade prejudicando os assistidos, como no caso do jovem André e seu patrão, no quarto capítulo do primeiro livro).

Rir da violência quixotesca é rir das pretensões de quem quer se fazer grande e poderoso por meio da violência; é rir da ilusão de se colocar acima dos demais e apontar o que é justo e injusto. Dom Quixote é alguém que, se vencesse, se transformaria num soberano ele tem consciência disso e afirma que poderá ser rei e dar a Sancho o título de conde (página 226 da Parte I) ou mesmo conquistar vários reinos e fazer de seu escudeiro rei de um deles (página 74 da Parte I) mas falha vergonhosamente por não conseguir submeter ninguém à sua força e por não obter o respeito e o temor que os violentos exigem.

\section{ANALOGIA ENTRE DOM QUIXOTE E O ESTADO}

O Engenhoso Fidalgo é como um Estado que não conseguiu se impor, um Soberano que caiu no ridículo devido aos seus sonhos grandiosos e a ineficácia em colocá-los em prática. Rir da "Fina Flor da Cavalaria Errante" é rir dos ambiciosos e pretensiosos que amparam seu poder no uso da força. Por isso este livro é extremamente subversivo. Ele desmistifica a violência e faz com que ela seja vista não como um atributo sagrado do soberano, como pode-se inferir da teoria do Direito Divino dos Reis, mas como algo possivelmente patético.

Rir do Quixote é rir dessa mentira e chamar de impostor a quem quer justificar monopólio do uso da violência/poder. É fazer, como queria Rousseau, uma revolta contra a desigualdade social 
entre os homens, instituída pela propriedade e o Estado ${ }^{3}$. É, afinal, ver que o uso da violência pelo Estado é uma realidade historicamente construída e contestar os que a chamam de "sagrada", "legítima" ou "benéfica"; é afirmar que o Direito e a jurisdição que a justificam são parciais e ideológicos.

Os revolucionários franceses fizeram um enorme esforço para se identificarem aos romanos e não é por acaso que o nome de César foi associado a reis que viveram depois de mais de mil anos de sua morte. As palavras "Kaiser" e "Kzar", dentre outras, não vêm de "César" à toa. Tudo isso faz parte do suporte ideológico que a superestrutura fornece à estrutura, dentro da teoria marxiana. Tudo isso é uma justificação intelectual da dominação violenta.

No livro de Cervantes não causa riso a violência, mas a pompa a que ela se atribui. Mesmo no caso do jovem André, em que a intervenção de Dom Quixote é extremamente danosa ao "assistido", não se ri do sofrimento imposto ao jovem graças ao Fidalgo, mas do fato deste se acreditar um poderoso e nobre cavaleiro; de se atribuir uma pompa e uma glória por seus feitos, sem que estes sejam dignos destas. É justamente o mesmo que o Estado tenta fazer por meio da ideologia dominante: atribuir pompa, muitas vezes sob o manto de "justiça", à violência. Revelar isso é o ato mais subversivo do livro de Cervantes.

Não é à toa que as ditaduras costumam reprimir a comédia que toca em assuntos políticos. No Brasil, a Ditadura Militar, que se estendeu de 1964 a 1985, combateu rigorosamente o humor, o riso. Muitos cartunistas foram presos e é notório o papel que eles tiveram na oposição ao regime e na formação da consciência política da população. Pode-se citar, por exemplo, as charges com a personagem O Amigo da Onça, de Péricles Maranhão, que desde a década de 1940 é símbolo de humor sarcástico e crítica social e política. Cabe

${ }^{3}$ Escreveu Rousseau, em seu Discurso Sobre a Origem e os Fundamentos da Desigualdade Entre os Homens: "O verdadeiro fundador da sociedade civil foi o primeiro que, tendo cercado um terreno, lembrou-se de dizer isto é meu e encontrou pessoas suficientemente simples para acreditá-lo. Quantos crimes, guerras, assassinatos, misérias e horrores não pouparia ao gênero humano aquele que, arrancando as estacas ou enchendo o fosso, tivesse gritado a seus semelhantes: 'Defendei-vos de ouvir esse impostor; estareis perdidos se esquecerdes que os frutos são de todos e que a terra não pertence a ninguém!’' (ROUSSEAU, 1997, 87). 
menção ainda do semanário $O$ Pasquim, que chegou a vender mais que jornais consagrados, como a Folha de São Paulo ou o Estado de São Paulo.

Se o humor tanto incomodou os detentores do poder violento é porque há uma relação de exclusão entre o riso e a violência. O riso é subversivo, na medida em que leva a questionar e estranhar o que o poder faz questão de dizer que é comum, válido e até sagrado (a força em prol de determinados interesses e ideais). Ao mesmo tempo, ele aproxima o que se coloca como distante e superior (o governante, Deus, ou qualquer outra autoridade ou figura de poder). Apenas se ri quando se está descontraído, à vontade; ou querendo quebrar a tensão, como se verá, à frente.

\section{A JUSTIÇA E A VIOLÊNCIA SAGRADA}

Burke (1993) associa o sublime ao sagrado, ao terror e à dor. De modo que há uma certa veneração e respeito ao que causa dor; a este sublime. Em seu desenvolvimento, o Estado, no Ocidente, tentou associar-se a esse terror sagrado e sublime que, para ser visto desta maneira, precisa se colocar como um grande outro, fora da sociedade, acima dela. $\mathrm{O}$ riso desfaz esse caráter sublime e traz o que está fora para perto, domesticando e tornando inofensivo o que antes era ameaçador. Não é à toa que muitos riem quando se sentem ameaçados; o riso desarma e ao mesmo tempo provoca.

Rir em um momento de tensão é uma tentativa de se aproximar daquele com quem se está em conflito, de apaziguar. Embora o riso também possa ser arma de conflito; ao menos o riso irônico. Mesmo esse, porém, demanda certa tranquilidade, certa descontração, ainda que na tensão: não se pode rir ironicamente de alguém que cause um profundo medo, sem estar seguro para isso. A este respeita-se e não se ri diante dele. Assim, o riso é traço de familiaridade, proximidade, de apaziguamento.

Platão proibiu a divulgação das obras homéricas em sua república ideal justamente por elas aproximarem o sagrado do humano. O sagrado tem por característica o ser separado do cotidiano pelo terror que impinge a quem dele se aproxima. Sua interdição é constante e imutável. Se a interdição deixar de existir, ele perderá seu caráter sacro. 
Ora, o humor não respeita nenhuma barreira ou interdição, por isso não combina com o sagrado (ao menos com a concepção de sagrado ocidental, legada pelo Judaísmo e por Platão). Sabe-se, com efeito, que Platão não via com bons olhos a comédia. Esta pode ser muito mais perigosa para o sagrado que as concepções homéricas de deuses semelhantes aos homens. Tampouco Aristóteles (2005) a valoriza. Para ele, ela era um gênero baixo, menos valioso que a tragédia ou a epopéia.

Assim, o estranhamento provocado por Dom Quixote diante da associação da violência com o sagrado e o grandioso pode ser muito útil para revisar o que se tem aceitado como fato. "Estranhamento" no sentido de que faz com que se ria dessa violência que quer apartar-se do comum, sem ser mais que um simples artifício de poder.

Ri-se do que é inusitado, inabitual. O riso é um meio de domesticar o que é diferente e novo. Esse novo, que sempre pode ter caráter ameaçador, por ser desconhecido e imprevisto, se torna aceitável com o riso. O fato dessa personagem cômica ser um guerreiro em busca de fama e glória possibilita ao leitor perceber o caráter ridículo que essa posição social pode comportar. Afinal, o guerreiro é humano e não divino, embora se acostume a aceitar a violência como algo sacro.

Girard mostra (2008) como a religião e toda a esfera do sagrado, em diferentes culturas, se liga à questão da violência e da justiça. Para ele, os sacrifícios rituais de muitas culturas e religiões eram um meio de apaziguar não somente os deuses, mas os homens. Essa era uma ferramenta cultural usada para cumprir a função do judiciário. Num mundo sem uma justiça estruturada institucionalmente para arbitrar conflitos, o que demanda um poder centralizado eficiente e duradouro, o sacrifício ritual dos hereges é um meio de fazer justiça. Só o Estado, historicamente, pôde atribuirse o monopólio da força e impedir que a violência se alastrasse, num ciclo sem fim de vinganças pessoais e novas provocações.

Assim, existiria uma violência sacra que impediria que a violência comum se alastrasse dentre os homens. Aquela faz do sacrifício uma cura, capaz de encerrar o ciclo de vinganças. Para isso, porém, o sacrificável deve ser alguém que não possa ser vingado; alguém distante o suficiente dos membros da comunidade. Se tênues são os laços que liguem a vítima à sociedade ninguém vai 
querer vingar sua morte e não será suscitado o início de uma nova onda de violência. $\mathrm{O}$ religioso, assim, se liga à justiça e à violência, corroborando-as ideologicamente:

Os procedimentos que permitem aos homens moderar sua violência são todos análogos: nenhum deles é estranho à violência. Poder-se-ia pensar que todos eles se encontram enraizados no religioso. Já vimos que o religioso propriamente dito identifica-se com os diversos modos da prevenção: mesmo os procedimentos curativos estão impregnados de religioso, tanto em sua forma rudimentar, que quase sempre é acompanhada de ritos sacrificiais, quanto na forma judiciária. Num sentido amplo, o religioso coincide certamente com a obscuridade que envolve em definitivo todos os recursos do homem contra sua própria violência, sejam eles preventivos ou curativos, com o obscurecimento que ganha o sistema judiciário quando este substitui o sacrifício. Esta obscuridade não é senão a transcendência efetiva da violência santa, legal, legítima, ante a imanência da violência culpada e legal. (GIRARD, R. 2008, p. 37).

Não foi por acaso, como se depreende da citação acima, que, no imaginário ocidental, o ato violento possa remeter ao sagrado. Tampouco é fruto do azar que aqueles que buscaram fortalecer seu poder tenham tentado se revestir de caráter sagrado. Essa associação parece uma evidente autopropaganda do soberano, mas ela não era e não é tão evidente assim. Como afirma Girard no trecho acima, há uma obscuridade associada ao sagrado e ao judiciário. Não se vê a punição ao criminoso sob o âmbito da ação de um homem sobre o outro, mas como uma categoria despersonificada e sagrada: a Justiça.

Como os sacerdotes que deveriam realizar os sacrifícios, os juízes dos países republicanos da atualidade são quase que separados da sociedade, como que consagrados. No Brasil, por exemplo, o cargo de juiz não apenas é vitalício, como este é impedido de se filiar a partidos políticos ou se candidatar a cargos eletivos. O que não deixa de ser uma institucionalização da "aura" que paira sobre os que aplicam a justiça. $\mathrm{O}$ artigo 95 da Constituição da República Federativa do Brasil de 1988 é claro:

Art. 95. Os juízes gozam das seguintes garantias:

I - vitaliciedade, que, no primeiro grau, só será adquirida após dois anos de exercício, dependendo a perda do cargo, nesse período, de 
deliberação do tribunal a que o juiz estiver vinculado, e, nos demais casos, de sentença judicial transitada em julgado;

II - inamovibilidade, salvo por motivo de interesse público, na forma do art. 93, VIII;

III- irredutibilidade de vencimentos, observado, quanto à remuneração, eque dispõem os arts. $37, \mathrm{XI}, 150, \mathrm{II}, 153, \mathrm{III}, \mathrm{e} 153, \S 2^{\circ}, \mathrm{I}$.

III - irredutibilidade de subsídio, ressalvado o disposto nos arts. 37, X e XI, 39, § $4^{\circ}, 150$, II, 153, III, e 153, § $2^{\circ}$, I. (Redação dada pela Emenda Constitucional $\mathrm{n}^{\circ}$ 19, de 1998)

Parágrafo único. Aos juízes é vedado:

I - exercer, ainda que em disponibilidade, outro cargo ou função, salvo uma de magistério;

II - receber, a qualquer título ou pretexto, custas ou participação em processo;

III - dedicar-se à atividade político-partidária.

IV - receber, a qualquer título ou pretexto, auxílios ou contribuições de pessoas físicas, entidades públicas ou privadas, ressalvadas as exceções previstas em lei; (Incluído pela Emenda Constitucional $\mathrm{n}^{\circ}$ $\underline{45, \text { de 2004) }}$

$\mathrm{V}$ - exercer a advocacia no juízo ou tribunal do qual se afastou, antes de decorridos três anos do afastamento do cargo por aposentadoria ou exoneração.

Se a justiça não é classificada como um ato de violência que responde a outro é por causa da sacralização, tão presente no imaginário coletivo, e geradora dessa "obscuridade". Trata-se de uma assimilação tão intensa dessa relação - uma introjeção tão fundante e essencial para a visão de mundo trazida pela ideologia dominante que a maioria das pessoas não percebe nos elementos jurídicos a violência sacra. Como se vê na citação acima, porém, o que é usado para moderar a violência, para contê-la, não deixa de ser mais violência. Violência sacra, porém. Legítima, necessária, fundamental e louvável; ao menos, aos olhos da ideologia dominante.

A associação do soberano ao sacro - evidente na doutrina sistematizada por Jean Bodin, Bossuet e outros acerca do Direito Divino dos Reis, na Europa Absolutista - só pôde enraizar-se porque agiu sobre um substrato já existente: a antiga e mitológica associação do sagrado com a violência. Se a burguesia, porém, conseguiu romper com a justificação divina do soberano enquanto um único homem, isso não significa que ela destruiu as ligações entre a 
sacralidade e a morte. Ela apenas transferiu essa sacralidade para a figura do povo, que mascara na verdade a defesa dos interesses de sua própria classe, enquanto líder desse povo. O parágrafo único do art. $1^{\circ}$ da Constituição de 1988 diz que "Todo o poder emana do povo, que o exerce por meio de representantes eleitos ou diretamente, nos termos desta Constituição", mas sabe-se que o poder nunca deixou de se concentrar nas mãos dos burgueses. $\mathrm{O}$ "povo" não passa de uma abstração sem utilidade, uma ficção jurídica que nunca se realiza enquanto sujeito de fato respeitado em seus direitos e prerrogativas.

Como denunciou Marx, a burguesia propagava a defesa dos direitos do homem ou do país para com isso arregimentar o apoio do proletariado para a defesa de seu próprios interesses. Não poderia ela conseguir tal apoio se não fizesse que o proletariado visse os interesses dela como interesses gerais; ou seja, "sagrados". A nova figura de soberano, pois, criada pela burguesia - o povo - é elevada à condição de sagrada e toda violência passa a ser bem-vinda, se perpetrada em nome dos interesses desse ente abstrato.

É esse poder associado ao sagrado, à glória, à pompa, ao nobre... que El ingenioso hidalgo Don Quijote de La Mancha vai ridicularizar, resgatando a consciência de que por trás dessas ações tidas por divinas - a justiça, o arbítrio, a violência sagrada - está um homem comum e não um deus maravilhoso. Este livro é como que a denúncia dessa alienação que mistifica e obscurece a realidade social.

\section{O "ESTRANHAMENTO" CIDADÃO OU A RESPONSABILIDADE PERANTE A SOCIEDADE DE MANTER-SE SEMPRE EM ESTADO DE VIGILÂNCIA CRÍTICA}

Por se estar habituado à pompa e à glória atribuídas à violência, o ocidental comum nem ao menos cogita que isto não precisa ser assim; alienado das outras possibilidades de vida social. Ele não questiona o óbvio, o corriqueiro, o normal... e não é à toa que adota essa postura: se questionasse tudo à sua volta, mesmo o que já "conhece", nada faria a não ser pensar e refletir. O que seria muito perigoso ao Estado, diga-se de passagem. 
A vida social exige que se deixe de lado, por um tempo, a reflexão para realizarmos coisas de ordem pragmática. Nos relatos de Platão, vê-se que mesmo Sócrates, o amante por excelência da reflexão, se via obrigado a deixar seus pensamentos quando seus amigos, cansados de esperar que ele viesse se juntar a eles, ousavam interpelá-lo (CANFORA, 2003).

Desta maneira, passa-se por uma espécie de suspensão da capacidade crítica - a já referida "obscuridade", então se instaura para poder-se realizar ações mais banais e simples, que não demandam o mesmo tempo e esforço que o refletir. Voltar a ter essa capacidade, nítida nas crianças e nos estrangeiros, que - ainda não habituados ao que os já iniciados estão - olham tudo com espanto e curiosidade, exige esforço e educação. Só com ela, pode-se repensar o que nos é transmitido como "normal".

Quando o "estranhamento" diante de uma situação é provocado por algo inusitado, isso causa o riso. $\mathrm{O}$ efeito cômico do chiste vem justamente daí: de apresentar de repente algo surpreendente, sem haver antes preparado os que o recebem. Quanto mais surpreendente a piada, mais engraçada será. Quanto menos se está preparado para refletir sobre esse inusitado que se mostra, mais ele cativará. Isso se dá porque ele reacende o estranhamento, tão necessário para o pensar. Ele, de certa forma, se liga, então, ao Thaumázein socrático, o "estranhamento" crítico diante do mundo, o gesto de ver algo como novo, estranho, e pensar sobre ele sem preconceitos ou fórmulas prontas, aberto a questionar tudo como se nada fosse certo ou bem conhecido.

El ingenioso hidalgo Don Quijote de La Mancha faz isso com maestria, gerando o riso pelo "estranhamento" que provocam as atitudes incomuns de suas protagonistas. Estranha-se que o Fidalgo da Mancha haja de modo diferente do usual; estranha-se que queira uma glória e pompa associada aos deuses e não aos homens; estranha-se sua capacidade de sonhar acordado, frente ao pragmatismo dos demais... e, assim, descobre mais sobre si mesmo aquele que lê esta obra.

Além disso, descobre mais sobre como, via de regra, a sociedade apresenta enorme facilidade em tomar por verdadeiras as regras e ideologias que não passam de constructo social. Descobre-se sobre como alguém passa grande parte de sua vida a agir sem pensar e que 
loucos e desajustados, às vezes, parecem ser os mais sãos; pois ao menos, não aceitam tudo que lhes é imposto, mas tentam criar uma nova realidade. Com efeito, eles, ao menos, percebem que isso é possível.

A obra-prima de Cervantes é, sem dúvidas, o principal panegírico do humor, em todo o Ocidente. Ao elevar o humor a uma função social de desmistificação do poder e da violência, seu autor institui um novo gênero literário: o das sátiras, paródias e alegorias humorísticas com foco no poder político. Mais que isso, ele contribui tremendamente para a construção da cidadania republicana e democrática. Afinal, ao ridicularizar o fidalgo violento, realizador da justiça, Cervantes está a rir não apenas de sua personagem, mas de toda a classe social que ela representa; está a criticar o poder instituído e a subverter a ordem. Ao rebaixar os nobres, ele eleva o povo.

Concluindo, El ingenioso hidalgo Don Quijote de La Mancha permite a realização de uma séria reflexão sobre a violência e sua apropriação pelo Estado, ao longo dos séculos; bem como do poder subversivo do riso diante desta ação repressora. Poder que faz dos comediantes seres temidos pelos ditadores.

Se é de responsabilidade coletiva garantir a manutenção de bens difusos, como a paz ou a preservação do meio ambiente, também é de responsabilidade social a manutenção da democracia. Este valor moderno não pode ser visto como garantido apenas porque as normas constitucionais a protegem. Infelizmente, estas normas nem sempre tem eficácia e, muitas vezes, são desrespeitadas justamente por aqueles que deveriam protegê-las, como ficou evidente com a decisão do STF acerca da prisão em segunda instância, que desrespeitou claramente o inciso LVII, do artigo $5^{\circ}$ da Constituição de 1988: "ninguém será considerado culpado até o trânsito em julgado de sentença penal condenatória".

Como afirmou o filósofo contratualista inglês John Locke, o direito à resistência diante de um governo injusto é um direito natural (e, portanto, inalienável) do ser humano. Assim, Locke deve ser visto como um dos filósofos mais importantes para a construção dos direitos civis e políticos. Para tanto, fiscalizar os abusos do poder e a repressão desmedida é de responsabilidade de cada um.

$\mathrm{Na}$ ocasião em que, porventura, o Estado esteja a ultrapassar os limites legais, éticos e morais a impostos a sua ação repressiva, deve o cidadão agir. São diversos os meios de que dispõe um 
cidadão num Estado Democrático de Direito para atuar a favor de seus interesses em combate à ação opressora do Estado, mas nem sempre há uma grande gama de meios disponíveis aos cidadãos de Estados Autoritários. Mesmo em casos extremos, no entanto, é possível usar do riso como arma subversiva de luta contra a tirania e o despotismo. Não há governo, por mais arbitrário e totalitário que seja, capaz de refrear a inteligência a favor do riso. As piadas inteligentes enganam a censura e se difundem muito rapidamente. Muitas vezes, uma piada bem feita pode ter mais poder para desacreditar um líder autoritário que centenas de libelos bem escritos, mas inacessíveis ao vulgo.

Por isso, o humor pode servir como guardião de nossa cidadania; desde que voltado criticamente contra os opressores. Afinal, os ditadores não sabem rir. A violência e o riso não combinam; o abuso e a liberdade não se coadunam. O riso é democrático e democratizante. É elemento de cidadania, quando colocado em prol dos que sofrem, contra os que oprimem. $O$ Pasquim, no Brasil, representou um elemento de cidadania e liberdade muito além do que se podia esperar. Quando o Estado governa não pelo povo, mas contra o povo, é preciso denunciá-lo e combatê-lo. Não há prova maior da decadência de um regime autoritário que sua dessacralização por meio do riso.

\section{REFERÊNCIAS}

ARISTÓTELES. "Poética”. In: Aristóteles. Coleção “Os pensadores”. $1^{a}$ Edição. São Paulo: Abril Cultural, 2005.

BENJAMIN, Walter. "Crítica da Violência. Crítica do Poder". In: BENJAMIN, W. Documentos de Cultura, Documentos de Barbárie. Org. W. Bolle. São Paulo: Cultrix/EDUSP, 1986, pp. 160-175.

BOBBIO, Norberto. O positivismo jurídico: lições de filosofia do direito. São Paulo: Ícone, 1995.

BOURDIEU, P. As Regras da Arte. Gênese e estrutura do campo literário. São Paulo: Companhia das Letras, 1996.

BRASIL. Código Penal (Decreto-Lei $\mathbf{n}^{\mathbf{0}} \mathbf{2 . 8 4 8}$, de 7 de dezembro de 1940). Disponível em: <http://www.planalto.gov.br/ccivil_03/decretolei/Del2848compilado.htm>. Acesso em 25/04/2018.

BRASIL. Constituição da República Federativa do Brasil de 1988. 
Disponível em:

<http://www.planalto.gov.br/ccivil_03/constituicao/constituicao.htm>.

Acesso em 25/04/2018.

BRASIL. Estatuto do Desarmamento (Lei $n^{0}$ 10.826, de 22 de dezembro de 2003). Disponível em: <http://www.planalto.gov.br/CCivil_03/leis/2003/L10.826.htm>. Acesso em 25/04/2018.

BRASIL. Estatuto do Índio (Lei $\mathbf{n}^{\mathbf{0}} \mathbf{6 . 0 0 1}$, de 19 de dezembro de 1973). Disponível em: <http://www.planalto.gov.br/ccivil_03/leis/16001.htm>. Acesso em 25/04/2018.

BURKE, E. Uma investigação filosófica sobre a origem de nossas idéias do sublime e do belo. Trad. Enid A. Dobránsky. Campinas: Papirus, 1993. CANFORA, L. Um Ofício Perigoso. $1^{\text {a }}$ Edição. São Paulo: Perspectiva, 2003. CERVANTES, M. El ingenioso hidalgo Don Quijote de La Mancha. Biblioteca Nacional de España. Disponível em: <http://quijote.bne.es/libro.html>. Acessado em 23/04/2018.

COMPARATO, F. K. “A servidão voluntária”. Carta Capital. 25/02/2011. Disponível em: <https://www.cartacapital.com.br/politica/a-servidaovoluntaria>. Acessado em 24/04/2018.

DURKHEIM, E. O Suicídio. São Paulo: WMF Martins Fontes, 2011

ELIAS, N. O processo civilizador. Tomo 2. $1^{\text {a }}$ Edição. Rio de Janeiro: Jorge Zahar, 1994.

GIRARD, R. A Violência e o Sagrado. Trad. Gambini, M. C. São Paulo: paz e Terra, 2008.

HOBBES, T. Leviatã. $1^{a}$ Edição. Trad. Claudia Berliner. São Paulo: Martins Fontes Editora, 2003.

LOCKE, J. Dois Tratados Do Governo Civil. Lisboa: Edições 70, 2006.

PlATÃO. A República. 1 ${ }^{a}$ Edição. Trad. Enrico Corvisieri. São Paulo: Editora Nova Cultural; Editora Best Seller, 2002.

ROUSSEAU, J.J. Discurso Sobre a Origem e os Fundamentos da Desigualdade Entre os Homens. In: Rousseau. Tomo 1.Coleção Os Pensadores. $1^{a}$ Edição. Trad. Lourdes Santos Machado. In: Rousseau. Coleção Os Pensadores. São Paulo: Nova Cultural, 1999. p. 5-163.

WEBER, M. A ética protestante e o espírito do capitalismo. São Paulo: Companhia das Letras, 2004.

. "Política como vocação". In: Ensaios de Sociologia. 5 ed. Rio de Janeiro: Livros Técnicos e Científicos, 1982.

VARAZZE, J. Legenda Aurea: Vidas de santos. Trad. Franco Jr, H. São Paulo: Cia das Letras, 2003. 